Volume 13 Nomor 1, November 2021, p. 033-046.

Faculty of Law, Universitas Kristen Maranatha

ISSN: 2085-9945 I e-ISSN: 2579-3520

Nationally Accredited Journal by SINTA

\title{
RELEVANSI PENGECUALIAN PRAKTIK MONOPOLI TERHADAP PERUSAHAAN BUMN DALAM MERGER 3 BANK SYARIAH BUMN
}

\author{
Chandra Manungsa Alit dan Yeti Sumiyati \\ Magister Ilmu Hukum Universitas Islam Bandung \\ chandramanungsaalit@gmail.com
}

Submitted: 2021-05-17 | Reviewed: 2021-09-02 | Accepted: 2021-11-08

\begin{abstract}
How to cite: Chandra Manungsa Alit dan Yeti Sumiyati. "Relevansi Pengecualian Praktik Monopoli Terhadap Perusahaan BUMN Dalam Merger 3 Bank Syariah BUMN". Dialogia Iuridica: Jurnal Hukum Bisnis dan Investasi, Vol. 13, No. 1, (2021), 033-046.
\end{abstract}

DOI:

https://doi.org/10.28932/di.v13i1.3618

\begin{abstract}
The 3 state-owned Islamic banks have merged and are effectively operating in February 2021. The merger has the potential to practice monopolistic practices and unfair business competition. This study examines the following issues: first, whether the merger of 3 state-owned sharia banks is included in the criteria for monopolistic practice as an activity prohibited in the Law on monopolistic practices and unfair business competition. Second, what is the relevance of the provisions of the exclusion of monopolistic practices on BUMN in the Law on monopolistic practices and unfair business competition to the merger of 3 BUMN sharia banks. This study uses a normative juridical method. The results showed that the merger or merger of 3 state-owned sharia banks could potentially lead to monopolistic practices and unfair business competition as prohibited by Law Number 5 of 1999 concerning Prohibition of Monopolistic Practices and Unfair Business Competition.
\end{abstract}

Keywords: Merger, Monopoly, Sharia Banks 


\section{PENDAHULUAN}

Perbankan syariah sebagai salah satu sistem perbankan yang relatif baru, jika dibandingkan dengan keberadaan perbankan konvensional yang telah mapan, saat ini terus berusaha mendapatkan eksistensinya. Disahkannya Undang-undang Nomor 21 Tahun 2008 tentang Perbankan Syariah (UU 21/2008) merupakan salah satu perwujudannya melalui ranah legal-formal. UU Perbankan Syariah yang diperjuangkan selama bertahun-tahun sampai akhirnya disahkan pada tahun 2008 diyakini bisa menjadi poin penting untuk mengakselerasi pertumbuhan bank syariah di Indonesia.

Paling tidak, UU tersebut memberikan kepastian hukum bagi semua pihak (stakeholder), sehingga menumbuhkan kepercayaan investor maupun masyarakat yang hendak berhubungan dengan bank syariah. Perkembangan tersebut tentu harus diapresiasi, terlepas dari segala kelebihan dan kekurangannya. Sementara bagi bank syariah sendiri, perkembangan tersebut tentu harus dijawab dengan peningkatan pelayanan terhadap nasabah, shariah compliance, dan peningkatan kompetensi sumber daya insani (SDI), sehingga misi falah dan rahmah li al-'alamin yang diusung oleh ekonomi Islam dapat tercapai. ${ }^{1}$

Bank Syariah menurut UU 21/2008, adalah bank yang menjalankan kegiatan usahanya berdasarkan Prinsip Syariah dan menurut jenisnya terdiri atas Bank Umum Syariah dan Bank Pembiayaan Rakyat Syariah. Sedangkan Perbankan Syariah atau sering disebut juga Perbankan Islam, yaitu perbankan yang pelaksanaannya berdasarkan hukum Islam atau syariat. Karena berdasarkan hukum Islam, maka perbankan syariah tidak mengenal adanya "bunga pinjaman" alias interest rate. Bunga pinjaman dianggap riba dan berdosa. Yang dikenal di perbankan syariah adalah "sistem bagi hasil" atau Nisbah yang prosesnya sama-sama diketahui dan disetujui oleh bank dan pihak nasabah. Kegiatan operasional Bank syariah menggunakan prinsip bagi hasil (Mudharabah). ${ }^{2}$

Merger atau Penggabungan menurut ketentuan Pasal 1 angka (9) Undang-undang Nomor 40 Tahun 2007 tentang Perseroan Terbatas (UU 40/2007) sebagaimana diubah dengan Undang-undang Nomor 11 Tahun 2020 tentang Cipta Kerja (UU 11/2020), adalah perbuatan hukum yang dilakukan oleh satu Perseroan atau lebih untuk menggabungkan diri dengan Perseroan lain yang telah ada yang mengakibatkan aktiva dan pasiva dari Perseroan yang menggabungkan diri beralih karena hukum kepada Perseroan yang menerima penggabungan dan selanjutnya status badan hukum Perseroan yang menggabungkan diri berakhir karena hukum.

Selain tunduk pada ketentuan UU 40/2007, pelaksanaan merger atau penggabungan perseroan juga harus memperhatikan syarat-syarat dan ketentuan-ketentuan yang berkaitan dengan larangan praktik monopoli dan persaingan usaha tidak sehat. Adapun ketentuan-ketentuan tersebut diatur dalam:

1 Luhur Prasetiyo, "Perkembangan Bank Syariah Pasca UU 21 Tahun 2008", Jurnal Al-Tahrir, Volume 12 No. 1, 2012, hlm. 43-63.

2 Agus Marimin, et.al, "Perkembangan Bank Syariah Di Indonesia", Jurnal Ilmiah Ekonomi Islam, Vol. 01 No. 02, 2015, hlm. 85-86. 
1. Undang-undang Nomor 5 Tahun 1999 tentang Larangan Praktik Monopoli dan Persaingan Usaha Tidak Sehat (UU 5/1999);

2. Peraturan Pemerintah Nomor 57 Tahun 2010 tentang Penggabungan atau Peleburan Badan Usaha dan Pengambilalihan Saham Perusahaan Yang Dapat Mengakibatkan Terjadinya Praktik Monopoli Dan Persaingan Usaha Tidak Sehat (PP 57/2010);

3. Peraturan Otoritas Jasa Keuangan Nomor 41/POJK.03/2019 tentang Penggabungan, Peleburan, Pengambilalihan, Integrasi, dan Konvensi Bank Umum (POJK 41/2019).

Praktik monopoli menurut ketentuan Pasal 1 angka 2 UU 5/1999 adalah pemusatan kekuatan ekonomi oleh satu atau lebih pelaku usaha yang mengakibatkan dikuasainya produksi dan atau pemasaran atas barang dan atau jasa tertentu sehingga menimbulkan persaingan usaha tidak sehat dan dapat merugikan kepentingan umum. Sedangkan pengertian persaingan usaha tidak sehat adalah persaingan antara pelaku usaha dalam menjalankan kegiatan produksi dan atau pemasaran barang dan atau jasa yang dilakukan dengan cara tidak jujur atau melawan hukum atau menghambat persaingan usaha. Munculnya Undang-Undang Nomor 5 Tahun 1999 Tentang Larangan Praktik Monopoli dan Persaingan Usaha Tidak Sehat merupakan puncak dari berbagai upaya yang mengatur masalah persaingan antar pelaku usaha dan larangan melakukan praktik monopoli.

Saat ini di Indonesia telah banyak bermunculan bank-bank yang menjalankan prinsip syariah, termasuk di antaranya adalah bank-bank milik BUMN yang telah mendirikan bank-bank syariah, antara lain Bank Rakyat Indonesia Syariah, Bank Negara Indonesia Syariah, dan Bank Syariah Mandiri. Pada awal Juli 2020, Kementerian BUMN mengumumkan rencana merger tiga bank syariah yang notabene anak perusahaan dari bank BUMN. Tiga bank syariah yang dimaksud adalah BRI Syariah (BRIS), BNI Syariah (BNIS), dan Bank Syariah Mandiri (BSM). Setelah menjadi satu, bank-bank syariah ini diharapkan lebih besar dan kuat serta menjadi alternatif pembiayaan. ${ }^{3}$ Rencana penggabungan/merger ketiga bank BUMN ini dimaksudkan agar bank syariah BUMN memiliki struktur permodalan yang kuat untuk mendukung bank syariah BUMN agar dapat bersaing di dalam ASEAN Economic Community. ${ }^{4}$ Meskipun demikian, merger atau penggabungan ketiga bank syariah BUMN tersebut dapat berpotensi melanggar larangan praktik monopoli dan persaingan usaha tidak sehat antar bank syariah yang beroperasi di dalam negeri, mengingat ketiga bank syariah tersebut masing-masing memiliki modal yang kuat, dengan besarnya aset pasca merger/penggabungan mencapai Rp. 214,6 triliun, dengan modal inti mencapai lebih dari Rp. 20,4 triliun ${ }^{5}$.

Ahmad Fauzan, "Risiko Yang Membayangi Proses Merger Bank Syariah Pelat Merah", https://tirto.id/risiko-yang-membayangi-proses-merger-bank-syariah-pelat-merah-f6qK, diakses pada tanggal 6 Maret 2021 pukul 20.15 WIB.

4 Anna Marina, et.al, "Bank BUMN Syariah Indonesia Yang Kuat Perlu Segera Didirikan Untuk Menyambut Asean Community 2015", tulisan yang disampaikan pada Seminar Nasional dengan Tema: Strategi Meningkatkan Kinerja yang diselenggarakan oleh Universitas Muhammadiyah Sidoarjo tanggal 15 Juni 2013, hlm. 2.

5 Fika Nurul Ulya, "Ini Nama Baru Hasil Merger 3 Bank Syariah BUMN", https://money.kompas.com/read/2020/12/11/093636126/ini-nama-baru-hasil-merger-3-bank-syariahbumn?page $=$ all, diakses pada tanggal 30 Januari 2021 pukul. 20.35 WIB. 
Berdasarkan latar belakang tersebut di atas, dalam tulisan ini penulis akan meneliti: (i) Apakah merger 3 bank syariah BUMN termasuk ke dalam kriteria praktik monopoli sebagai kegiatan yang dilarang dalam UU praktik monopoli dan persaingan usaha tidak sehat? dan (ii) Bagaimana relevansi ketentuan pengecualian praktik monopoli terhadap BUMN dalam UU praktik monopoli dan persaingan usaha tidak sehat terhadap merger 3 bank syariah BUMN?

\section{PEMBAHASAN}

\section{Merger 3 Bank Syariah BUMN Dikaitkan Dengan Kriteria Praktik Monopoli Sebagai Kegiatan Yang Dilarang Dalam UU Praktik Monopoli Dan Persaingan Usaha Tidak Sehat}

Pada tanggal 21 Oktober 2020 telah dipublikasikan Ringkasan Rancangan Penggabungan Usaha (merger) antara PT Bank BRI Syariah Tbk, PT Bank Syariah Mandiri dan PT Bank BNI Syariah. Ketiganya adalah bagian dari Badan Usaha Milik Negara (BUMN). Hasil dari merger akan membuat bank tersebut memiliki total aset Rp. 214,6 triliun. Bank tersebut akan menjadi perusahaan terbuka dan tetap ada dalam Bursa Efek Indonesia dengan code BRIS. Pemegang saham pada bank hasil merger yaitu PT Bank Mandiri (Persero) Tbk. (BMRI) 51,2\%, PT Bank Negara Indonesia (Persero) Tbk. (BNI) 25,0\%, PT Bank Rakyat Indonesia (Persero) Tbk. (BRI) 17,4\%, DPLK BRI Saham Syariah 2\% dan publik 4,4\%. ${ }^{6}$ Kemudian pada tanggal 15 Desember 2020 telah disetujui merger ketiga bank syariah dalam Rapat Umum Pemegang Saham Luar Biasa (RUPSLB). Bank hasil merger akan diberi nama PT Bank Syariah Indonesia Tbk dan bergabung secara efektif pada 1 Februari $2021 .^{7}$

Mergernya tiga bank Syariah menjadi Bank Syariah Indonesia (BSI) diprediksi akan berpengaruh cukup signifikan terhadap kesadaran masyarakat terhadap produk Perbankan Syariah. Dengan dana kelola yang naik secara signifikan, diperkirakan dana literasi keuangan untuk produk BSI akan naik secara drastis sehingga masyarakat lebih cepat dalam mengetahui produk-produk Bank Syariah. ${ }^{8}$

Merger atau Penggabungan menurut ketentuan Pasal 1 angka (9) 40/2007 sebagaimana diubah dengan UU 11/2020, adalah perbuatan hukum yang dilakukan oleh satu Perseroan atau lebih untuk menggabungkan diri dengan Perseroan lain yang telah ada yang mengakibatkan aktiva dan pasiva dari Perseroan yang menggabungkan diri beralih karena hukum kepada Perseroan yang menerima penggabungan dan selanjutnya

6 Bank Negara Indonesia (BNI), "Rampungkan Rencana Merger 3 Bank Syariah, Bank Hasil Penggabungan akan Berevolusi Jadi Bank Syariah Nasional Terbesar", yang dikutip dari Jurnal Nabilah Anika, Nabila Indah Chairunnisa dan Aditya Wahyu Saputro, "Potensi Praktik Monopoli Dalam Merger Bank Syariah Indonesia: Tinjauan Hukum Ekonomi Islam dan Hukum Larangan Monopoli”, Jurnal Hukum Lex Generalis, Vol. 2 No. 2, 2021, hlm. 181.

7 Happy Fajrian $(E d$.$) , "Rencana Merger Disetujui Bank Syariah Indonesia Beroperasi 1$ Februari", yang dikutip dari Nabilah Anika, Nabila Indah Chairunnisa dan Aditya Wahyu Saputro, "Potensi...", Ibid.

8 Bagus Romadhon dan Sutantri, "Koreksi Merger Tiga Bank Syariah dan Kesadaran Masyarakat Terhadap Produk Perbankan Syariah”, Jurnal At-Tamwil, Vol. 3 No. 1, Maret 2021, hlm. 97. 
status badan hukum Perseroan yang menggabungkan diri berakhir karena hukum. Merger/penggabungan tersebut merupakan salah satu bentuk restrukturisasi korporasi.

Menurut Patrick A. Gaughan, restrukturisasi korporat adalah serangkaian aktivitas perusahaan yang bertujuan untuk memperbaiki kinerja di masa mendatang. Berbagai aktivitas itu adalah dimaksudkan untuk menata kembali bagian dari perusahaan yang bisa saja meliputi aset perusahaan, pendanaan perusahaan, ataupun jenis usaha pokok perusahaan (core business). Pada umumnya restrukturisasi korporat dikelompokkan dalam tiga kelompok besar yaitu: restrukturisasi portofolio, restrukturisasi keuangan, dan restrukturisasi organisasi. ${ }^{9}$

Restrukturisasi dalam ranah perbankan bisa meliputi aktivitas melepaskan anak perusahaan (sister company) atau mengubah jenis usaha pokok bank (core business). Termasuk di dalam kategori ini adalah mengonversi dari bank konvensional menjadi bank syariah dengan basis Islam (Islamic banking). Sedangkan alasan melakukan restrukturisasi korporat diantaranya adalah: 1) berhasil diidentifikasi adanya peluang baru (new opportunities), 2) terjadinya perubahan akses permodalan dan kebutuhan keuangan, serta 3) perubahan kebijakan pemerintah (government policy) sebagai antisipasi atas perubahan tatanan ekonomi dunia. ${ }^{10}$

Seperti diketahui bahwa setelah dilakukannya merger atau penggabungan ketiga bank syariah milik BUMN ini, menjadikan bank syariah BUMN tersebut sebagai satusatunya bank syariah yang memiliki modal yang besar dibandingkan bank-bank syariah lainnya. Sebagai contoh, Bank Muamalat sebagai bank pertama yang menerapkan sistem syariah di Indonesia, modal inti dan modal pelengkap per kuartal III 2020 tercatat sebanyak Rp. 3,78 triliun. ${ }^{11}$ Angka tersebut sangat jauh di bawah Bank Syariah Indonesia hasil merger atau penggabungan ketiga bank milik BUMN, yang modal intinya saja mencapai Rp. 22,61 triliun ${ }^{12}$ dan sampai saat ini angkanya terus merangkak naik. Dengan modal yang besar tersebut, Bank Syariah Indonesia saat ini tercatat sebagai bank dengan urutan ketujuh terbesar di industri perbankan nasional.

Hal tersebut berpotensi menimbulkan terjadinya praktik monopoli serta persaingan usaha tidak sehat bagi perbankan-perbankan syariah di Indonesia. Monopoli menurut ketentuan Pasal 1 ayat (1) UU 5/1999 adalah penguasaan atas produksi dan atau pemasaran barang dan/atau atas penggunaan jasa tertentu oleh satu pelaku usaha atau satu

9 Patrick A. Gaughan, Mergers, Acquisitions, and Corporate Restructurings, Fifth Edition, New Jersey: John Wiley \& Sons, Inc., 2011, hlm. 389, yang dikutip dalam Anna Marina, Sentot Imam Wahjono, Ezif Muhammad Fahmi, Bank BUMN Syariah Indonesia Yang Kuat Perlu Segera Didirikan Untuk Menyambut Asean Community 2015, tulisan yang disampaikan pada Seminar Nasional dengan Tema: Strategi Meningkatkan Kinerja yang diselenggarakan oleh Universitas Muhammadiyah Sidoarjo tanggal 15 Juni 2013.

10 Ibid, hlm. 447.

11 Laurensius Marshall Sautlan Sitanggang, "BPKH bakal setor modal ke Bank Muamalat, begini rincian rencana investasinya", https://keuangan.kontan.co.id/news/bpkh-bakal-setor-modal-ke-bankmuamalat-begini-rincian-rencana-investasinya diakses pada tanggal 27 April 2021 pukul 13.06 WIB.

12 Azizah Nur Alfi, "Bank Syariah Indonesia (BSI) Terbentuk, Market Share Perbankan Syariah Tumbuh?”, https://finansial.bisnis.com/read/20210216/231/1356972/bank-syariah-indonesia-bristerbentuk-market-share-perbankan-syariah-tumbuh diakses pada tanggal 27 April 2021 pukul 13.19 WIB. 
kelompok pelaku usaha. Monopoli dalam pasal tersebut bermakna suatu penguasaan/kuasa terhadap suatu bisnis/ atau usaha tertentu oleh satu pelaku usaha atau satu kelompok pelaku usaha. Hal ini bertujuan menghindari posisi dominan seorang/sekelompok pelaku usaha dan disisi lain posisi pesaingnya menjadi lemah, maka semakin lama pelaku usaha yang melakukan penguasaan akan semakin menguasai pasaran. ${ }^{13}$

Akibat hukum merger terhadap persaingan usaha tidak sehat adalah kegiatan merger tersebut tidak menutup kemungkinan akan terjadinya konsentrasi pasar yang dilarang oleh Undang-Undang Nomor 5 Tahun 1999 tentang Anti Monopoli. ${ }^{14}$ Larangan praktik monopoli dan persaingan usaha tidak sehat sebagai akibat dari adanya penggabungan atau peleburan badan usaha dapat dilihat dari beberapa ketentuan peraturan perundang-undangan sebagai berikut:

1. Ketentuan Pasal 28 ayat (1) dan ayat (2) Undang-Undang Nomor 5 Tahun 1999 tentang Anti Monopoli;

2. Ketentuan Pasal 2 ayat (1) dan ayat (2) Peraturan Pemerintah Nomor 57 Tahun 2010 tentang Penggabungan atau Peleburan Badan Usaha dan Pengambilalihan Saham Perusahaan Yang Dapat Mengakibatkan Terjadinya Praktik Monopoli Dan Persaingan Usaha Tidak Sehat (PP 57/2010);

3. Ketentuan Pasal 6 ayat (1) Peraturan Otoritas Jasa Keuangan Nomor 41/POJK.03/2019 tentang Penggabungan, Peleburan, Pengambilalihan, Integrasi, dan Konvensi Bank Umum;

Berdasarkan ketentuan Pasal 2 ayat (2) PP 57/2010, Praktik monopoli dan persaingan usaha tidak sehat terjadi jika badan usaha hasil penggabungan, diduga melakukan: a) perjanjian yang dilarang; b) kegiatan yang dilarang; dan/atau penyalahgunaan posisi dominan. Selain itu, UU 5/1999 juga telah menyebutkan tiga bentuk larangan bagi para pelaku usaha terkait monopoli dan persaingan usaha tidak sehat, antara lain:

1. Perjanjian yang dilarang sebagaimana yang terdapat di dalam Bab III, Pasal 4 sampai dengan Pasal 16, yaitu perjanjian yang bertujuan untuk: a) melakukan praktik oligopoli, b) menetapkan harga (price fixing), c) membagi wilayah (market allocation), d) pemboikotan (boycott), e) kartel (cartel), f) trust, g) oligopsoni, h) integrasi vertikal (vertical integration), i) perjanjian tertutup (exlusive dealings) dan j) perjanjian dengan pihak luar negeri.

2. Kegiatan yang dilarang terdapat pada Bab IV, Pasal 17 sampai dengan Pasal 24, adalah kegiatan yang dilakukan oleh pelaku usaha seperti: monopoli, monopsoni, penguasaan pasar dan persekongkolan (collusive tendering). Perbedaan antara

13 Gilang Yudha Wiarawan dan Hartanto, "Larangan Praktek Monopoli dan Persaingan Usaha Tidak Sehat Dalam Industri Sepeda Motor (Kajian Putusan Mahkamah Agung Nomor 217 K/PDT.SUSKPPU/2019)", Jurnal Dialogia Iuridica, Volume 12 No. 2, April 2021, hlm. 54.

14 Megawati Rihi dan I Ketut Sudantra, "Merger Dalam Hubungannya Dengan Persaingan Usaha Tidak Sehat", e-Journal Ilmu Hukum Kertha Semaya, Vol. 01 No. 04, Mei 2013, hlm. 5. 
kegiatan yang dilarang dengan perjanjian yang dilarang terletak pada jumlah pelaku usaha. Dalam perjanjian yang dilarang paling tidak ada dua pihak pelaku usaha, karena suatu perjanjian menghendaki sedikitnya dua subjek hukum. Sementara dalam kegiatan yang dilarang tidak tertutup untuk dilakukan oleh satu pelaku usaha. ${ }^{15}$

3. Larangan yang berkaitan dengan posisi dominan terdapat pada Bab V, Pasal 25 sampai dengan Pasal 29.

Undang-undang tersebut bertujuan untuk memelihara pasar kompetitif dari pengaruh kesepakatan dan konspirasi yang cenderung mengurangi dan atau menghilangkan persaingan. ${ }^{16}$ Kemudian dalam ketentuan POJK 41/2019, terdapat salah satu syarat yang harus dilakukan oleh bank sebelum melakukan merger/penggabungan, yaitu sebagaimana diatur dalam Pasal 6 yang berbunyi: Bank yang akan melakukan penggabungan, peleburan, pengambilalihan, atau integrasi wajib membuat pernyataan kepada OJK dan RUPS bahwa penggabungan, peleburan, pengambilalihan, atau integrasi dilakukan dengan memperhatikan kepentingan Bank, masyarakat, persaingan sehat dalam melakukan usaha, dan jaminan tetap terpenuhinya hak pemegang saham dan karyawan sesuai dengan ketentuan peraturan perundang-undangan.

Meskipun POJK 41/2019 telah mewajibkan kepada bank yang akan melakukan merger/penggabungan untuk membuat pernyataan terkait persaingan sehat dalam melakukan usaha, serta dengan memperhatikan ketentuan anti monopoli dan persaingan usaha tidak sehat, maka perbankan dilarang untuk melakukan praktik-praktik yang dapat dikualifikasikan sebagai praktik monopoli dan persaingan usaha tidak sehat.

Dengan melihat perkembangan Bank Syariah Indonesia sebagai bank hasil merger atau penggabungan ketiga bank syariah BUMN saat ini, dapat menimbulkan ketimpangan dalam persaingan usaha antar bank syariah di Indonesia. Salah satu dampak yang diakibatkan oleh penggabungan 3 bank syariah BUMN ini adalah dikhawatirkan dapat mengurangi jumlah bank syariah di Indonesia sebagai pilihan bagi masyarakat atau konsumen, sehingga membuat persaingan usaha menjadi tidak berjalan dengan baik.

Menurut Biro Riset Infobank (birI), gabungan tiga BUS tersebut asetnya menjadi Rp227,91 triliun pada September 2020 dan Rp239,56 triliun pada akhir 2020. BSI menguasai 60,77\% pangsa aset Bank Umum Syariah (BUS) dan 40,53\% terhadap total aset BUS ditambah 20 unit usaha syariah (UUS). Selain makin dominan di pasar perbankan syariah, posisi BSI di panggung industri perbankan patut diperhitungkan karena berada di urutan ketujuh bank terbesar di Tanah Air. ${ }^{17}$ Oleh karena itu, dengan

15 Hikmahanto Juwana, “Sekilas Tentang Hukum Persaingan dan UU No. 5 Tahun 1999”, Jurnal Magister Hukum, Vol. 1 No. 1, 1999, UII Yogyakarta, hlm. 34, yang dikutip dalam Jurnal Azhari Akmal Tarigan, "Praktek Monopoli Dan Persaingan Usaha Tidak Sehat Dalam Perspektif Hukum Ekonomi dan Hukum Islam", Jurnal Mercatoria, Vol. 9 No. 1, 2016, hlm. 38.

16 Mashur Malaka, "Praktek Monopoli Dan Persaingan Usaha”, Jurnal Al- 'Adl, Vol. 7 No. 2, Juli 2014, hlm. 51.

17 Rezkiana Nisaputra, “Peta Pasar Setelah Merger BSI, Bagaimana Kinerja Bank Muamalat?”, diakses dari https://infobanknews.com/kumpulan-berita-bank-hari-ini/peta-pasar-setelah-merger-bsibagaimana-kinerja-bank-muamalat-\%EF\%BB\%BF/ diakses pada tanggal 10 Mei 2021 pukul 16.48 WIB. 
munculnya Bank Syariah Indonesia sebagai bank syariah terbesar di Indonesia, akan dapat mempengaruhi kebijakan-kebijakan pasar secara sepihak sebagai bank syariah yang memiliki posisi dominan, misalnya dalam menentukan besaran bagi hasil bagi konsumen, atau menawarkan produk-produk perbankan syariah yang lebih menarik dibandingkan dengan bank-bank syariah lainnya. Sehingga lambat laun bank syariah swasta yang tidak dapat bersaing dengan Bank Syariah Indonesia, terutama jika bank-bank syariah swasta tersebut tidak dapat memberikan keuntungan yang lebih baik bagi nasabah atau konsumen, maka akan ditinggalkan oleh nasabahnya dan mati.

\section{Relevansi Ketentuan Pengecualian Praktik Monopoli Terhadap BUMN Dalam UU Praktik Monopoli Dan Persaingan Usaha Tidak Sehat Terhadap Merger 3 Bank Syariah BUMN}

Pemerintah Indonesia telah menerapkan larangan bagi pelaku usaha melakukan praktik monopoli dan persaingan usaha tidak sehat, sebagaimana dapat dilihat dari beberapa ketentuan seperti UU 5/1999, PP 57/2010, dan POJK 41/2019. Bisa dipahami mengapa persaingan usaha tidak sehat dan praktik monopoli dilarang karena dapat menimbulkan distorsi pasar. Pasar menjadi tidak seimbang dan pada gilirannya hargaharga tidak lagi dikendalikan oleh hukum pasar, melainkan ditentukan oleh sekelompok orang yang menguasai kekuatan pasar. Akibat lebih jauh, yang merasakan dampaknya adalah masyarakat atau konsumen. Demikian buruknya akibat yang ditimbulkan oleh praktik monopoli dan persaingan usaha tidak sehat ini, maka undang-undang ini dilahirkan. ${ }^{18}$

Di beberapa negara, hukum persaingan dikenal dengan istilah Antitrust Laws seperti di Amerika Serikat atau Antimonopoly Law seperti di Jepang atau Restrictive Trade Practice Law seperti di Australia. Sedangkan di Indonesia istilah yang dipakai adalah "Hukum Persaingan" atau "Hukum Antimonopoli." Terlepas dari penyebutannya yang bervariasi, secara umum tujuan pokok dari hukum persaingan adalah menjaga; a) agar persaingan antar pelaku usaha tetap hidup, b) agar persaingan yang dilakukan antar pelaku usaha dilakukan secara sehat dan c) agar konsumen tidak dieksploitasi oleh pelaku usaha. ${ }^{19}$

Terkait dengan penggabungan atau merger ketiga bank syariah BUMN, ketentuan Pasal 28 ayat (1) UU 5/1999 telah memberikan batasan bahwa pelaku usaha dilarang melakukan penggabungan atau peleburan badan usaha yang dapat mengakibatkan terjadinya praktik monopoli dan atau persaingan usaha tidak sehat.

Namun demikian, ternyata UU 5/1999 secara tersirat memberikan pengecualian kepada Badan Usaha Milik Negara untuk melakukan praktik monopoli. Hal ini dapat dilihat dari ketentuan Pasal 51 UU 5/1999, yang menyebutkan bahwa monopoli dan atau pemusatan kegiatan yang berkaitan dengan produksi dan atau pemasaran barang dan atau jasa yang menguasai hajat hidup orang banyak serta cabang-cabang produksi yang

18 Azhari Akmal Tarigan, "Praktek Monopoli Dan Persaingan Usaha Tidak Sehat Dalam Perspektif Hukum Ekonomi Dan Hukum Islam”, Jurnal Mercatoria, Vol. 9 No. 1, 2016, hlm. 57.

19 Hikmahanto Juwana, Op. cit... hlm. 59. 
penting bagi negara diatur dengan undang-undang dan diselenggarakan oleh Badan Usaha Milik Negara dan atau badan atau lembaga yang dibentuk atau ditunjuk oleh Pemerintah.

Dalam ketentuan tersebut, terdapat beberapa unsur utama yang perlu diperhatikan, antara lain:

1. Adanya unsur "monopoli dan atau pemusatan kegiatan yang berkaitan dengan produksi dan atau pemasaran barang dan atau jasa";

2. Adanya unsur "menguasai hajat hidup orang banyak serta cabang-cabang produksi yang penting bagi negara";

3. Adanya unsur "diatur dengan undang-undang";

4. Adanya unsur "diselenggarakan oleh Badan Usaha Milik Negara dan atau badan atau lembaga yang dibentuk atau ditunjuk oleh Pemerintah".

Ningrum Natasha Sirait, dkk berpendapat bahwa pengertian diatur "dengan undang-undang" merupakan syarat legal dari negara untuk melakukan monopoli dan/atau pemusatan kegiatan atas barang dan jasa yang menguasai hajat hidup orang banyak serta cabang-cabang produksi yang penting bagi negara. Dengan demikian, praktik monopoli dan/atau pemusatan kegiatan oleh negara tersebut hanya dapat dilakukan setelah diatur terlebih dahulu dalam undang-undang (UU), bukan melalui peraturan perundangundangan di bawah undang-undang misalnya Peraturan Pemerintah (PP). Undangundang tersebut harus mencantumkan secara jelas tujuan monopoli dan/atau pemusatan kegiatan serta mekanisme pengendalian dan pengawasan negara dalam penyelenggaraan monopoli dan/atau pemusatan kegiatan tersebut, sehingga tidak bisa mengarah pada praktik monopoli dan/atau persaingan usaha tidak sehat ${ }^{20}$.

Selain syarat legal tersebut di atas, praktik monopoli yang dapat dilakukan oleh BUMN terbatas pada usaha-usaha yang berkaitan langsung dengan hajat hidup orang banyak serta cabang-cabang produksi yang penting bagi negara. Menurut Bab II Pedoman Pelaksanaan Pasal 51 Undang-undang Nomor 5 Tahun 1999, Penafsiran mengenai "barang dan jasa yang menguasai hajat hidup orang banyak" memiliki makna yang sangat luas. Berdasarkan teori hukum dan penafsiran sistematis terhadap unsur ini, maksud barang dan/atau jasa yang menguasai hajat hidup orang banyak adalah yang memiliki fungsi:

a. Alokasi, yang ditujukan pada barang atau jasa yang berasal dari sumber daya alam yang dikuasai negara untuk dimanfaatkan bagi sebesar-besarnya kemakmuran rakyat;

b. Distribusi, yang diarahkan pada barang dan/atau jasa yang dibutuhkan secara pokok oleh masyarakat, tetapi pada suatu waktu tertentu atau terus menerus tidak dapat dipenuhi pasar; dan atau

20 Ningrum Natasya Sirait, "Ikhtisar Ketentuan Persaingan Usaha, The Indonesia Netherlands National Legal Reform Program (NLRP), 2010”, yang dikutip dalam Nanda Narendra Putra, Isu Monopoli dan Kepailitan di Tengah Holding BUMN Tambang, diakses dari https://www.hukumonline.com/berita/baca/lt5a376d99c3672/isu-monopoli-dan-kepailitan-di-tengahholding-bumn-tambang?page=all, diakses pada tanggal 31 Maret 2021 pukul 20.59 WIB. 
c. Stabilitas, yang berkaitan dengan barang dan/atau jasa yang harus disediakan untuk kepentingan umum, seperti barang dan/atau jasa dalam bidang pertahanan keamanan, moneter, dan fiskal, yang mengharuskan pengaturan dan pengawasan bersifat khusus.

Selain itu, salah satu unsur dalam ketentuan pengecualian praktik monopoli sebagaimana dimaksud dalam Pasal 51 UU 5/1999 yaitu "cabang-cabang produksi yang penting bagi Negara". Pengertian cabang-cabang produksi yang penting bagi Negara adalah ragam usaha produksi atau penyediaan barang dan atau jasa yang memiliki sifat:

a. Strategis, yaitu cabang produksi atas barang dan/atau jasa yang secara langsung melindungi kepentingan pertahanan negara dan menjaga keamanan nasional; atau

b. Finansial, yaitu cabang produksi yang berkaitan erat dengan pembuatan barang dan/atau jasa untuk kestabilan moneter dan jaminan perpajakan, dan sektor jasa keuangan yang dimanfaatkan untuk kepentingan umum.

Berdasarkan hal-hal tersebut di atas, bidang usaha perbankan syariah tidak termasuk ke dalam barang dan jasa yang menguasai hajat hidup orang banyak serta cabang-cabang produksi yang penting bagi Negara. Oleh karenanya, jika praktik monopoli yang dilakukan oleh BUMN pada bidang usaha perbankan syariah, maka tindakan BUMN tersebut dapat diduga telah melanggar ketentuan larangan praktik monopoli dan persaingan usaha tidak sehat, serta tidak memenuhi kriteria pengecualian praktik monopoli sebagaimana dimaksud dalam Pasal 51 UU 5/1999.

Dengan demikian, dapat disimpulkan bahwa tidak semua BUMN dikecualikan dari ketentuan Pasal 51 UU 5/1999. Hanya BUMN yang masuk kategori kegiatan yang menguasai hajat hidup orang banyak sajalah yang dalam menjalankan kegiatannya, termasuk kegiatan usaha merger, dapat menerobos kriteria praktik monopoli dan persaingan usaha yang tidak sehat. Oleh karena itu, pelaksanaan merger atau penggabungan ketiga Bank Syariah BUMN seharusnya tidak dikecualikan oleh ketentuan Pasal 51 UU 5/1999 karena bidang usahanya tidak berkaitan dengan hajat hidup orang banyak serta cabang-cabang produksi yang penting bagi Negara.

Sebagai sebuah perseroan yang tunduk pada UU 40/2007 sudah seharusnya pelaksanaan merger atau penggabungan ketiga bank syariah BUMN juga menerapkan prinsip Good Corporate Governance (GCG). Salah satu prinsip GCG adalah responsibility, yaitu prinsip pentaatan terhadap peraturan perundang-undangan yang berkaitan dengan aktivitas perusahaan. ${ }^{21}$ Dalam merger atau penggabungan ketiga bank syariah BUMN juga harus menerapkan prinsip responsibility. Sebagai wujud dari prinsip responsibility, maka UU 5/1999 menjadi rujukan utama dalam pelaksanaan merger, sehingga seharusnya pelaksanaan 3 bank syariah BUMN ini dikaji ulang dan diteliti betul terpenuhi atau tidaknya posisi dominan dari aktivitas merger tersebut.

21 Yeti Sumiyati, "Peranan BUMN dalam Pelaksanaan Tanggung Jawab Sosial Perusahaan Untuk Meningkatkan Kesejahteraan Rakyat”, Jurnal Hukum Ius Quia Iustum, Vol. 20 No. 3, 2013, hlm. 465. 
Dalam pelaksanaan merger atau penggabungan 3 bank syariah BUMN menjadi Bank Syariah Indonesia ini, setidaknya ada beberapa alasan mengapa bank syariah milik BUMN ini tidak boleh melakukan praktik monopoli sebagaimana telah dilarang oleh peraturan perundang-undangan di Indonesia, antara lain: Pertama, bidang usaha perbankan, khususnya perbankan syariah, bukanlah bidang usaha yang berkaitan langsung dengan "hajat hidup orang banyak". Kedua, bidang usaha perbankan syariah tidak termasuk ke dalam salah satu "cabang-cabang produksi yang penting bagi negara" seperti halnya minyak dan gas bumi yang merupakan sumber daya alam yang strategis yang memegang peranan penting dalam penyediaan bahan baku industri, pemenuhan kebutuhan energi di dalam negeri, dan penghasil devisa negara yang penting, sehingga pengelolaannya harus dikuasai oleh negara agar dapat dimanfaatkan bagi sebesarbesarnya kemakmuran dan kesejahteraan rakyat. Ketiga, tidak ada peraturan perundangundangan yang secara spesifik memperbolehkan atau mengizinkan BUMN untuk melakukan praktik monopoli di bidang usaha perbankan syariah. Ketiga hal tersebut merupakan syarat yang harus dipenuhi oleh BUMN apabila ingin melakukan praktik monopoli atas nama negara. Oleh karenanya, pengecualian praktik monopoli oleh BUMN tidak relevan diberlakukan dalam bidang usaha perbankan syariah.

Oleh karenanya, dibutuhkan peran aktif dari Komisi Pengawas Persaingan Usaha (KPPU) untuk mengawasi secara ketat pelaksanaan merger atau penggabungan 3 bank syariah BUMN menjadi Bank Syariah Indonesia ini, mengingat merger atau penggabungan 3 bank syariah BUMN ini berpotensi melakukan praktik-praktik monopoli dan persaingan usaha tidak sehat. Sebagai badan yang bertugas mengawasi pelaksanaan Undang-Undang Anti Monopoli, KPPU berwenang mengadakan pemeriksaan dan penyelidikan kepada pelaku usaha yang diduga melakukan praktik monopoli dan/atau persaingan usaha yang tidak sehat. ${ }^{22}$

KPPU sebagai lembaga negara komplementer memiliki tugas yang kompleks dalam mengawasi praktik persaingan usaha tidak sehat oleh para pelaku usaha. Hal ini disebabkan, semakin masifnya aktivitas bisnis dalam berbagai bidang dengan modifikasi strateginya dalam memenangkan persaingan antar kompetitor, di sinilah KPPU memerankan perannya sebagai penjaga (watchdog) dan pengawas pasar (market survelienence) agar tidak terjadi persaingan yang tidak sehat. ${ }^{23}$

\section{PENUTUP}

Merger 3 bank syariah BUMN termasuk merger dengan kriteria praktik monopoli, yaitu kegiatan yang dilarang dalam UU 5/1999 dengan pertimbangan kegiatan usaha dibidang perbankan, khususnya perbankan syariah, tidak termasuk ke dalam kegiatan usaha yang menguasai hajat hidup orang banyak serta cabang-cabang produksi yang

22 I Ketut Karmi Nurjaya, "Peranan KPPU Dalam Menegakkan Undang-Undang Nomor 5 Tahun 1999 Tentang Larangan Praktek Monopoli Dan Persaingan Usaha Tidak Sehat", Jurnal Dinamika Hukum, Vol. 9 No. 1, Januari 2009, hlm. 85-86.

23 Mulyadi, et al, "Efektivitas peran Komisi Pengawas Persaingan Usaha (KPPU) dalam penanganan kasus persaingan usaha tidak sehat", Jurnal Ilmiah Galuh Justisi, Vol. 5 No. 1, Maret 2017, hlm. 86. 
penting bagi Negara, karena tidak memenuhi unsur-unsur sebagaimana diuraikan dalam Pedoman Pelaksanaan Pasal 51 Undang-undang Nomor 5 Tahun 1999.

Pasal 51 UU 5/1999 tidak lagi relevan diterapkan pada kasus merger atau penggabungan 3 bank syariah BUMN, karena tidak memenuhi kriteria yang ditetapkan dalam pasal tersebut sehingga kebijakan ini seharusnya ditinjau kembali. Langkah yang perlu dilakukan oleh KPPU saat ini adalah mengawasi aktivitas bisnis dari Bank Syariah Indonesia agar tidak keluar dari rambu-rambu persaingan usaha yang sehat.

\section{DAFTAR PUSTAKA}

\section{Buku}

Ningrum Natasya Sirait, Ikhtisar Ketentuan Persaingan Usaha, Jakarta: The Indonesia Netherlands National Legal Reform Program, 2010.

Patrick A. Gaughan, Mergers, Acquisitions, and Corporate Restructurings, Fifth Edition, New Jersey: John Wiley \& Sons, Inc., 2011.

\section{Jurnal}

Agus Marimin, et.al, "Perkembangan Bank Syariah Di Indonesia", Jurnal Ilmiah Ekonomi Islam, Vol. 01 No. 02, 2015.

Anna Marina dan Didin Fatihudin, "Pasar Oligopoli di Indonesia (Kasus Trading Term dan Dominasi Carrefour pada Pasar Ritel Modern di Indonesia”, Balance Economics, Bussines, Management and Accounting Journal, Th. V/No. 9, 2008.

Anna Marina, et.al, "Bank BUMN Syariah Indonesia Yang Kuat Perlu Segera Didirikan Untuk Menyambut Asean Community 2015", tulisan yang disampaikan pada Seminar Nasional dengan Tema: Strategi Meningkatkan Kinerja yang diselenggarakan oleh Universitas Muhammadiyah Sidoarjo tanggal 15 Juni 2013.

Azhari Akmal Tarigan, "Praktek Monopoli Dan Persaingan Usaha Tidak Sehat Dalam Perspektif Hukum Ekonomi Dan Hukum Islam”, Jurnal Mercatoria, Vol. 9 No. 1, 2016.

Bagus Romadhon dan Sutantri, "Koreksi Merger Tiga Bank Syariah dan Kesadaran Masyarakat Terhadap Produk Perbankan Syariah", Jurnal At-Tamwil, Vol. 3 No. 1, 2021.

Gilang Yudha Wiarawan dan Hartanto, "Larangan Praktek Monopoli dan Persaingan Usaha Tidak Sehat Dalam Industri Sepeda Motor (Kajian Putusan Mahkamah Agung Nomor 217 K/PDT.SUS-KPPU/2019)”, Jurnal Dialogia Iuridica, Vol. 12 No. 2, 2021.

Hikmahanto Juwana, "Sekilas Tentang Hukum Persaingan dan UU No 5 Tahun 1999", Jurnal Magister Hukum, Vol. 1 No. 1, 1999.

I Ketut Karmi Nurjaya, "Peranan KPPU Dalam Menegakkan Undang-Undang Nomor 5 Tahun 1999 Tentang Larangan Praktek Monopoli Dan Persaingan Usaha Tidak Sehat", Jurnal Dinamika Hukum, Vol. 9 No. 1, 2009.

Luhur Prasetiyo, "Perkembangan Bank Syariah Pasca UU 21 Tahun 2008”, Jurnal AlTahrir, Vol. 12 No. 1, 2012. 
Dialogia luridica: Jurnal Hukum Bisnis dan Investasi

Volume 13 Nomor 1, November 2021

Mashur Malaka, "Praktek Monopoli Dan Persaingan Usaha”, Jurnal Al- 'Adl, Vol. 7 No. 2, 2014.

Megawati Rihi dan I Ketut Sudantra, "Merger Dalam Hubungannya Dengan Persaingan Usaha Tidak Sehat”, e-Journal Ilmu Hukum Kertha Semaya, Vol. 01 No. 04, 2013.

Mulyadi, et.al, "Efektivitas peran Komisi Pengawas Persaingan Usaha (KPPU) dalam penanganan kasus persaingan usaha tidak sehat." Jurnal Ilmiah Galuh Justisi, Vol. 5 No. 1, 2017.

Nabilah Anika, et.al, "Potensi Praktik Monopoli Dalam Merger Bank Syariah Indonesia: Tinjauan Hukum Ekonomi Islam dan Hukum Larangan Monopoli”, Jurnal Hukum Lex Generalis, Vol. 2, No. 2, 2021.

Yeti Sumiyati, "Peranan BUMN dalam Pelaksanaan Tanggung Jawab Sosial Perusahaan Untuk Meningkatkan Kesejahteraan Rakyat”, Jurnal Hukum Ius Quia Iustum Vol. 20 No. 3, Juli 2013.

\section{Peraturan Perundang-undangan}

Undang-undang Nomor 40 Tahun 2007 tentang Perseroan Terbatas.

Undang-undang Nomor 11 Tahun 2020 tentang Cipta Kerja.

Undang-undang Nomor 21 Tahun 2008 tentang Perbankan Syariah.

Undang-undang Nomor 5 Tahun 1999 tentang Larangan Praktik Monopoli dan Persaingan Usaha Tidak Sehat.

Peraturan Pemerintah Nomor 57 Tahun 2010 tentang Penggabungan atau Peleburan Badan Usaha dan Pengambilalihan Saham Perusahaan Yang Dapat Mengakibatkan Terjadinya Praktik Monopoli Dan Persaingan Usaha Tidak Sehat

Peraturan Menteri BUMN Nomor: PER-01/MBU/2011 tentang Penerapan Tata Kelola Perusahaan yang Baik (Good Corporate Governance/GCG) pada BUMN.

Peraturan Otoritas Jasa Keuangan Nomor 41/POJK.03/2019 tentang Penggabungan, Peleburan, Pengambilalihan, Integrasi, dan Konvensi Bank Umum.

Pedoman Pelaksanaan Pasal 51 Undang-undang Nomor 5 Tahun 1999.

\section{Pranata Lain}

Azizah Nur Alfi, Bank Syariah Indonesia (BSI) Terbentuk, "Market Share Perbankan Syariah Tumbuh?", https://finansial.bisnis.com/read/20210216/231/1356972/bank-syariah-indonesiabris-terbentuk-market-share-perbankan-syariah-tumbuh diakses pada tanggal 27 April 2021.

Fika Nurul Ulya, "Ini Nama Baru Hasil Merger 3 Bank Syariah BUMN", https://money.kompas.com/read/2020/12/11/093636126/ini-nama-baru-hasilmerger-3-bank-syariah-bumn?page=all diakses pada tanggal 30 Januari 2021

Isu Monopoli dan Kepailitan di Tengah Holding BUMN Tambang, https://www.hukumonline.com/berita/baca/lt5a376d99c3672/isu-monopoli-dankepailitan-di-tengah-holding-bumn-tambang?page=all diakses pada tanggal 31 Maret 2021 
Dialogia luridica: Jurnal Hukum Bisnis dan Investasi

Volume 13 Nomor 1, November 2021

Laurensius Marshall Sautlan Sitanggang, "BPKH bakal setor modal ke Bank Muamalat, begini rincian rencana investasinya", https://keuangan.kontan.co.id/news/bpkhbakal-setor-modal-ke-bank-muamalat-begini-rincian-rencana-investasinya diakses pada tanggal 27 April 2021.

Rezkiana Nisaputra, "Peta Pasar Setelah Merger BSI, Bagaimana Kinerja Bank Muamalat?", https://infobanknews.com/kumpulan-berita-bank-hari-ini/petapasar-setelah-merger-bsi-bagaimana-kinerja-bank-muamalat-\%EF\%BB\%BF/ diakses pada tanggal 10 Mei 2021.

Risiko yang Membayangi Proses Merger Bank Syariah Pelat Merah, https://tirto.id/risiko-yang-membayangi-proses-merger-bank-syariah-pelatmerah-f6qK diakses pada tanggal 6 Maret 2021. 